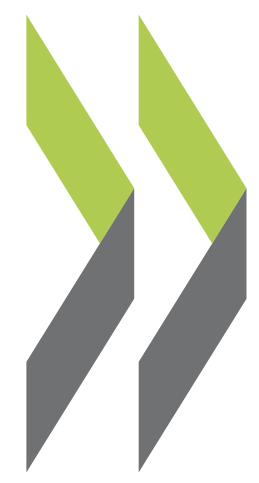

OECD Economics Department Working Papers No. 1475

Firms at the productivity frontier enjoy lower effective

\title{
David Bartolini
}

taxation

https://dx.doi.org/10.1787/b102e5fc-en 


\section{FIRMS AT THE PRODUCTIVITY FRONTIER ENJOY LOWER EFFECTIVE}

TAXATION

ECONOMICS DEPARTMENT WORKING PAPERS No. 1475

\section{By David Bartolini}

OECD Working Papers should not be reported as representing the official views of the OECD or of its member countries. The opinions expressed and arguments employed are those of the author(s).

Authorised for publication by Alain de Serres, Deputy Director, Policy Studies Branch, Economics Department.

All Economics Department Working Papers are available at www.oecd.org/eco/workingpapers.

JT03433306 
OECD Working Papers should not be reported as representing the official views of the OECD or of its member countries. The opinions expressed and arguments employed are those of the author(s).

Working Papers describe preliminary results or research in progress by the author(s) and are published to stimulate discussion on a broad range of issues on which the OECD works.

Comments on Working Papers are welcomed, and may be sent to OECD Economics Department, 2 rue André Pascal, 75775 Paris Cedex 16, France, or by e-mail to eco.contact@oecd.org.

All Economics Department Working Papers are available at www.oecd.org/eco/workingpapers

This document and any map included herein are without prejudice to the status of or sovereignty over any territory, to the delimitation of international frontiers and boundaries and to the name of any territory, city or area.

(C) OECD (2018)

You can copy, download or print OECD content for your own use, and you can include excerpts from OECD publications, databases and multimedia products in your own documents, presentations, blogs, websites and teaching materials, provided that suitable acknowledgment of OECD as source and copyright owner is given. All requests for commercial use and translation rights should be submitted to rights@oecd.org 


\section{ABSTRACT/RÉSUMÉ}

\section{Firms at the productivity frontier enjoy lower effective taxation}

Slow productivity growth in advanced economies holds back income gains and therefore improvements in well-being. Sluggish productivity gains in aggregate hide a growing gap between firms at the frontier, which display sustained productivity growth, and the rest of firms whose productivity stagnates. The empirical analysis - based on firm-level data for the period 1998-2014 - uncovers the existence of a tax burden gap alongside the productivity gap: firms at the frontier pay less for each dollar of profits than lagging firms. This heterogeneous impact of taxation may hinder productivity diffusion, as it reduces incentives (and opportunities) for lagging firms to catch up with the frontier. The negative impact of taxation is particularly important when associated with cash constraints, weak demand and other framework conditions (e.g. labour market legislation, trade openness). The analysis shows that complementing tax incentives with policies to ease cash constraints would help to narrow the productivity gap.

\section{JEL Classification: D24; H25}

Keywords: Productivity, effective business taxation, access to credit, market regulation

$$
* * * * *
$$

\section{Les entreprises les plus productives bénéficient d'une imposition réelle plus faible}

La faible croissance de la productivité dans les économies avancées freine la hausse des revenus et par conséquent l'amélioration du niveau de vie. La médiocrité des gains de productivité globale masque un fossé croissant entre les entreprises les plus performantes, dont la productivité enregistre une croissance soutenue, et les autres, qui ne font que stagner dans ce domaine. La présente analyse empirique - établie sur la base de données microéconomiques relatives à la période 1998-2014 - révèle l'existence d'un écart au niveau de la charge fiscale parallèlement à l'écart de productivité : pour chaque dollar de bénéfice, les entreprises les plus productives s'acquittent d'un impôt moins élevé que les entreprises à la traine. Cette hétérogénéité au niveau de l'impact de la fiscalité risque de nuire à la diffusion de la productivité, du fait qu'elle n'encourage pas les entreprises à la traine à rattraper leur retard par rapport aux entreprises à forte productivité (et limite leurs possibilités d'y parvenir). L'impact négatif de la fiscalité est particulièrement important lorsqu'il s'accompagne de contraintes de liquidité, d'une demande atone et d'autres conditions cadres (par exemple, législation sur le marché du travail ou ouverture des échanges). L'analyse montre qu'associer aux incitations fiscales des politiques visant à atténuer les contraintes de liquidité permettrait de réduire l'écart de productivité.

Classification JEL : D24; H25

Mots clés : productivité, fiscalité réelle des entreprises, accès au crédit, règlementation des marchés 


\section{Table of contents}

1. Introduction and main findings 5

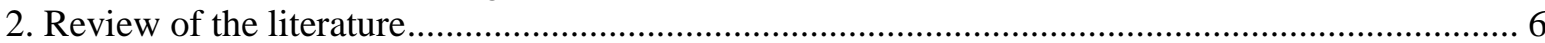

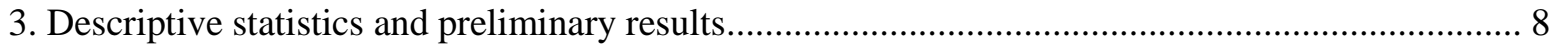

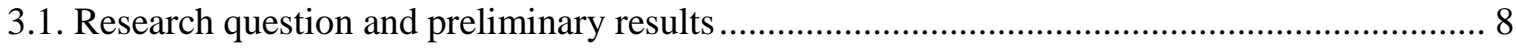

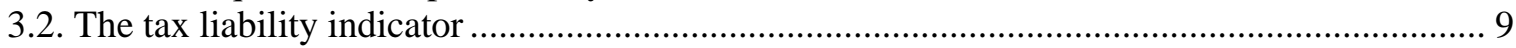

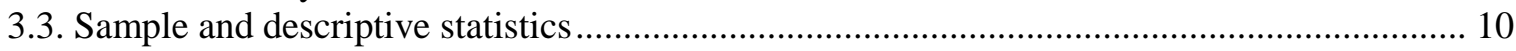

3.4. The burden of taxation according to the productivity level .................................................... 11

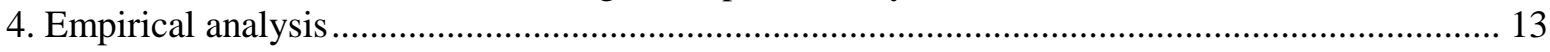

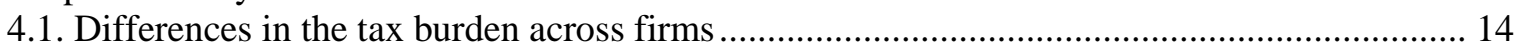

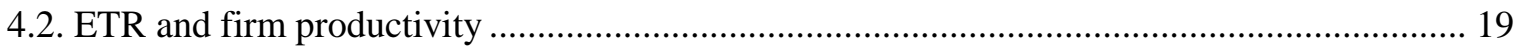

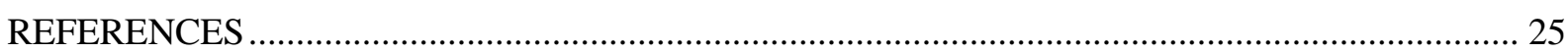

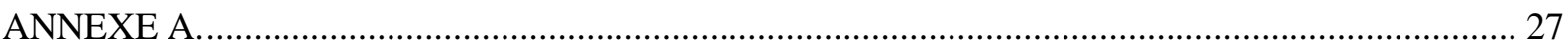

\section{Tables}

Table 1. Dataset description

\section{Figures}

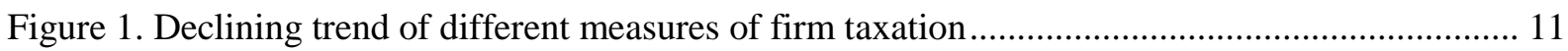

Figure 2. Evolution of the effective tax rate by productivity level.................................................... 12

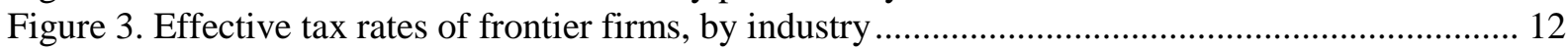

Figure 4. Effective taxation in the manufacturing and service sectors............................................ 13

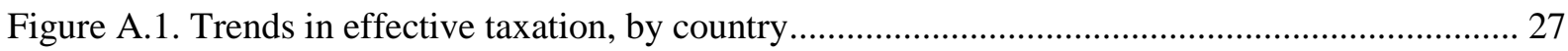




\title{
Firms at the productivity frontier enjoy lower effective taxation
}

\author{
David Bartolini ${ }^{1}$
}

\section{Introduction and main findings}

1. The sluggish productivity growth experienced by most OECD countries hides a growing gap between firms at the frontier, which have been displaying steady growth, and the rest, whose productivity has been stagnating (Andrews, et al., 2016). This increasing gap is a sign that the diffusion mechanism has weakened. Many reasons could explain this phenomenon, including the increasing complexity of the innovative process, which prevents most firms from innovating; institutional regidities that hinder the re-allocationion of resources from less to more productive uses; and the lack of reources or opportunities to acquire new technoloiges and innovative production processes.

2. The differential tax treatment of firms can slow catching-up and hinder technology diffusion. The tax burden reduces the net return of investments and the amount of cash available to firms, thus affecting the incentive and capacity to invest in and adopt new technologies that may reduce the gap with the frontier. Most important for technology diffusion is the heterogeneous effect of tax policies on firms. For instance, each firm's tax liability varies with characteristics such as the industrial sector, the firm's age, or the capital to worker ratio. It may also depend on the level of productivity. Firms at the productivity frontier may rely on superior management practices that better cope with fiscal obligations; they may have more possibilities to avoid taxation, in particular if they are multinationals; and they may rely on a more tax-friendly capital composition.

3. Although the tax system applies equally to all firms, the effective amount of taxes paid by firms may vary. The ORBIS database (Bureau Van Dijk) provides firm-level invormation on balance sheets allowing the calculation of a wide range of economic and financial indicators across several OECD countries. In particular, it is possible to calculate the effective tax rate (ETR) that each firm faces as the ratio between the amount of taxes paid and profits. Although this measure is highly correlated with the amount of corporate tax paid, it comprises all types of taxes the firm is liable of (except payroll taxes and employers' social security contributions).

4. The empirical analysis provides the following evidence on the correlation between effective tax burden and firms' level of productivity:

- Existence of a tax gap: Since 2005, firms at the productivity frontier pay less tax for each dollar of profits than the other firms in the sample; the creation and persistence of this tax gap has been tested controlling for sector, country and year fixed effects, as well as different specifications of the econometric model. Many

1. The author worked in the OECD Economics Department, when the paper was written. He would like to thank Boris Cournéde, Peter Gal and Peter Hoeller (all from the Economics Department), Tibor Hanappi and Giorgia Maffini (Centre for Tax Policy and Administration) for comments and suggestions, and Celia Rutkoski for technical assistance. 
factors may have contributed to this phenomenon, including the high share of multinational firms (MNEs) at the frontier, which can exploit mismatches between tax systems. However, this cannot be the only cause, as frontier firms' effective tax rate has been declining since 1999 and is only since 2005 below that of lagging firms.

- The composition of capital matters: The share of intangible capital of frontier firms has increased faster than that of the other firms in both the manufacturing and non-financial service sectors, contributing to their lower tax liability. Intangible capital tends to be taxed less than tangible capital (e.g. because of a shorter amortisation period, or lower taxataion due to patent boxes).

5. The lower tax burden of the most productive firms could be a consequence of tax incentives to boost productivity and growth. However, these policies have failed to reach the majority of firms, as the productivity gap is still increasing and aggregate productivity grows at a sluggish pace.

6. This "failure" in part stems from constraints that reduce the productivity diffusion from the frontier. These include cash-flow reasons, as taxation reduces the amount of available funding and difficulties in accessing credit. There is therefore a case for policies to complement tax incentives by removing constraints to invest. The emprical analysis of the impact of effective taxation on multifactor productivity suggests that:

- Cash constraints and a low level of solvency magnify the negative effect of taxation on productivity for firms in the middle of the productivity distribution, thus representing an obstacle to technology diffusion from the frontier.

- Rigidities in the labour market appear to exacerbate the negative impact of taxation for firms in the middle of the productivity distribution.

- Barriers to trade seem to exacerbate the negative impact of taxation on multifactor productivity. Higher trade barriers appear to be particularly harmful for firms in the middle of the productivity distribution. Together with taxation, trade barriers can generate a bottleneck for productivity gains of firms lagging behind the frontier.

7. The rest of the paper is organised as follows. The next section provides an overview of the existing literature on the taxation of firms and productivity. Section 3 discusses the data and indicators used in the empirical analysis. The empirical analysis is presented in Section 4: Section 4.1 investigates the existence of a tax gap coinciding with the productivity gap; Section 4.2 looks at the impact of taxation on multifactor productivity focusing on the interaction between taxation and firm characteristics, as well as framework conditions.

\section{Review of the literature}

8. Many empirical studies point at the negative impact of the corporate income tax on innovation and investment (see for instance Djankov et al., 2010, and the many references therein). Among the most recent contributions, Sorbe and Johansson (2017) provide evidence of the detrimental effect of the effective marginal tax rate on firm's investment decisions. Mukherjee et al. (2017) show that an increase in the state-level corporate tax within the United States significantly reduces patenting, R\&D investment and the introduction of new products. This work exploits differences in the level of taxation of firms operating in contiguous states, so that the economic environment is 
similar, but tax rates differ. Other factors may interact with taxation in discouraging investment, for instance, the availability of credit and the functioning of financial markets.

9. The tax gap could also be due to the presence of multinational enterprises (MNEs) at the productivity frontier. The literature on taxation of MNEs has extensively investigated the capacity of global firms to avoid taxation by shifting profits to jurisdictions with a more lenient tax code (see for instance Leibrecht and Hochgatterer, 2010, for a review of this vast literature). Also OECD research provides robust evidence of tax planning by MNEs (Johansson, et al., 2017). There are several practices that MNEs use to reduce their overall tax burden: shifting profits to low-tax countries by strategically manipulating intra-group transactions, so that intangible assets are concentrated in low-tax countries or debt, and thus interest payments, in high-tax countries; locating intellectual property activities - i.e. patents - in countries that provide preferential tax treatment for such activities; exploiting mismatches between national tax systems to obtain double nontaxation or double deductions. Johansson et al. (2017) test two possible channels through which MNEs can avoid taxation: (i) profit shifting, by testing whether MNEs with affiliates in countries with a lower statutory tax rate tend to report less profits than other MNEs (with similar characteristics but the location of affiliates); and (ii) differences in tax rates, by testing the difference in the tax rate faced by MNEs with respect to domestic companies. They find that MNEs with ties in low-tax countries tend to report lower profits and that (large) MNEs display a lower tax rate than domestic firms, on average by 4 to $8 \frac{1}{2}$ percentage points. The tax rate of small MNEs is not significantly different from the tax rate of domestic firms.

10. The rise of MNEs, however, does not represent the only source of the reduction in effective tax rates. In a study of US firms, Dyreng et al. (2017) provides evidence in support of the idea that this decline is also the result of other causes such as a more taxfriendly composition of capital.

11. Firm-level data allow to investigate the individual response of firms to tax incentives. Zwick and Mahon (2017), for instance, provide empirical evidience of differences in the magnitude of the response to tax incentives by firms of different size and financial position. They conduct a difference-in-differences analysis of two tax incentive episodes in the United States, related to changes in the depreciation timing of investment. They find that firms in sectors where investments are short-lived react less to the tax incentive than firms that invest in long-lived capital. Furthermore, they find firms that are cash constrained or have difficulties to access credit are more responsive to the investment stimulus. This shows that the impact of tax policies depends on the context, that is both firm specific (like the availability of cash), and systemic (like the functioning of financial markets). In the authors' own words "financial frictions and non-convex adjustment costs can amplify the effects of both temporary and permanent policies" (Zwick \& Mahon, 2017, p. 223). ${ }^{2}$ The authors acknowledge that if the effect of the tax stimulus is to substitute future investments for current ones, the impact of such policies for productivity growth and long-term output gains are uncertain.

12. Related to the present work, the IMF has recently published studies that investigate the role of the tax system for firm productivity (IMF, 2017; Dabla-Norris et al.,

2. Non-convex adjustment costs are due to the existence of large fixed costs of investments. Firms do not adjust their investment strategy in a continuous way but lump investment until the tax policy puts the firm above the adjustment threshold. This is another source of heterogeneity as the threshold varies across firms. 


\section{$\mathbf{8}$ | ECO/WKP(2018)23}

2017). The focus is on productivity differences across countries, which can be explained by resource misallocation driven by differential tax treatment. The impact of differential tax treatment on productivity depends on the type of industry. Different tax policies have a different impact according to the importance of the source of taxation for the industry. For instance, a tax disparity which favours buildings over machinery would adversely affect an industry relying more on machinery, so that the misallocation in the most affected industry will be higher in countries with a larger tax differential (IMF, 2017). Differential tax treatment can be measured by marginal effective tax rates (METRs) on specific types of investment elaborated by the Oxford Centre for Business Taxation.

13. Tax compliace costs can also be a source of tax discrimination. Dabla-Norris et al. (2017) show that tax compliance costs are related to the productivity gap as they are higher for small and young firms as compared to older and larger firms. The main novelty of the work is the creation of an index of tax administration quality that can be used for cross-country comparisons and allows to assess the impact of the quality of the tax administration on firms' performance. In the context of the present work, large tax administration costs amplify the importance of a "capable" management in effectivly dealing with the tax system. In other words, it should not be only a matter of size and experience but also a matter of efficient versus inefficient management. Although the main idea of compliance costs is that firms may pay the same amount of taxes but some would need more resources to do it, so that small and young firms are disproportionally affected, there is also the possibility that high compliance costs are associated with the complexity of the tax system, so that firms with a more capable management are not only more efficient in dealing with the tax aministration but they actually pay less on average.

14. The main contribution of this work is that differential tax treatment emerges not just because of tax design but also because of firm characteristics. For instance, taxation is more harmful for cash-constrained firms than for firms that have easy access to credit or financial markets.

\section{Descriptive statistics and preliminary results}

\subsection{Research question and preliminary results}

15. The main goal of the analysis is twofold: first to investigate whether effective taxation is negatively correlated with productivity and, if this is the case, to investigate whether this link is associated with the productivity gap. These two research questions can be expressed as:

1. Does tax liability systematically differ with the level of productivity? What are the features of frontier firms that decrease their average tax liability?

2. Does the tax gap represent an obstacle to the productivity growth of firms lagging behind the frontier?

16. The persistence and widening of the productivity gap could depend on insufficient investment by lagging firms and poor re-allocation of resources from less to more productive firms. Most of the literature on corporate income taxation focuses on the distortion of investment plans. Taxation reduces the net return on investment and together with weak demand could discourage firms to invest. ${ }^{3}$ But even when firms find it

3. There are empirical investigations that do not find statistical evidence for a relationship between taxation and investment, but they often consider statutory tax rates rather than the effective rate that firms face when deciding to invest. 
profitable to invest in new technology, money needs to be found to finance such projects. Taxation reduces the cash flow to fund investment and innovative projects through selffinancing. Firms could turn to external sources, such as bank loans or issuing bonds or equity. The access to financial resources is linked to both systemic characteristics (e.g. the efficiency of the financial system at the country level) and sector and firm characteristics (e.g. debt level, liquidity ratio, solvency ratio, size and availability of collateral). For instance, small and young firms tend to be more credit-constrained and tend to rely more on profits to finance investments.

17. For UK companies, Maffini et al. (2016) find a signficant positive effect of bonus depreciation on firms' investment, which is entirely due to a reduction in user costs (cost of capital effect). Lower taxation may also free cash to finance investment (cash flow effect). The latter should be particularly important when credit constraints are binding. The authors, however, find that the effect of the bonus depreciation in the United Kingdom is mainly due to the user cost effect, as firms respond to the bonus even before the tax payment is due.

18. The channels discussed above, however, could not explain the tax gap if they were to affect all firms in the same way. It is the heterogeneity of the impact that can explain the gap. The same tax system may affect frontier firms differently than other firms for several reasons. First, firms at the frontier often are multinational, and they may exploit tax system mismatches across countries and benefit from preferential tax treatments. The effective tax rate indicator used in this study is already net of any profit shifting practice: for instance, the amount of profits registered in the firm's account is already lower, because of tax planning. Therefore, the available data reflect the capacity to exploit mismatches between different tax systems and preferential treatment. Second, irrespective of being an MNE, the most productive firms tend to rely more on intangible capital that is usually taxed at a lower rate than tangible capital. They could also invest in green technology which again is favourably treated by most tax systems. Higher profitability means also that credit constraints are less binding because of the possibility to self-finance the investment. A final reason refers to better management practices that allow frontier firms to adapt their operations to the tax code and thus pay less tax. This effect should also be linked to size, as the availability of human resources is also important. Bloom and Van Reenen (2010) find that firms that are better managed tend to be larger, display higher productivity, grow faster and have higher survival rates. Mankins and Garton (2017) show that companies with the best management practices produce operating margins that are $30 \%$ to $50 \%$ above the average. If management practices of frontier firms are better than practices in other firms, they could also explain their lower tax liability, as managers tend to deal more efficiently with the tax system.

\subsection{The tax liability indicator}

19. The indicator of taxation included in the ORBIS database includes all cash payments in local currency for tax-related reasons that each firm made during the year. For the analysis this value is normalised by the pre-tax accounting profits:

$$
E T R=\frac{\text { Tax }}{\text { Operating }+ \text { financial profits }}
$$


This represents the effective tax rate each firm paid during the fiscal year. ${ }^{4}$ It is a backward looking measure of taxation because it is determined by past decisions of the company, including tax planning decisions. For this reason the indicator cannot be used to assess the behavioural reactions of firms. It is nevertheless useful to consider differences in tax liability across firms (Johansson, et al., 2017). In particular it can provide insights into systematic differences in tax treatment of different firms.

20. Only firms that display profits larger than their tax liability are included. This avoids problems with carry forward regulations where firms may receive money from the tax administration or cases in which the tax liability is larger than firms' profits.

\subsection{Sample and descriptive statistics}

21. The ORBIS database provides an extensive coverage of firms across OECD countries. However, since there is no systematic criterion guiding the inclusion of firms in the sample, the resulting coverage is unbalanced along several dimensions:

- The sample does not have the same size in all years; coverage tends to increase over time;

- The sample is much larger for some countries than others;

- Small firms tend to be under represented.

22. In order to ensure a good degree of cross-country comparability and a large sample in each country, the analysis is restricted to six countries: France, Germany, Italy, Korea, Sweden and the United Kingdom. The sample consists of more than 2 million observations with a predominance of firms from France and Italy (Table 1).

Table 1. Dataset description

\begin{tabular}{|c|c|c|c|c|c|c|c|c|}
\hline \multirow[t]{2}{*}{$\begin{array}{l}\text { Countries } \\
\text { (ISO codes) }\end{array}$} & \multirow[t]{2}{*}{ Obs. } & \multirow[t]{2}{*}{ Share of total } & \multicolumn{6}{|c|}{ Share by sector } \\
\hline & & & Manufacturing & Energy \& water & Construction & Trade & Services (non-fin.) & Unclassified \\
\hline DEU & 181977 & 9.51 & 30.53 & 5.73 & 9.12 & 20.85 & 32.78 & 1.00 \\
\hline FRA & 491525 & 25.68 & 26.97 & 1.27 & 14.51 & 26.18 & 29.77 & 1.29 \\
\hline GBR & 357081 & 18.65 & 26.80 & 1.11 & 9.92 & 21.20 & 39.05 & 1.91 \\
\hline ITA & 522482 & 27.29 & 49.67 & 1.85 & 8.54 & 15.62 & 22.78 & 1.53 \\
\hline KOR & 202117 & 10.56 & 52.38 & 2.28 & 11.78 & 10.43 & 22.45 & 0.68 \\
\hline SWE & 159049 & 8.31 & 21.73 & 2.11 & 10.32 & 20.65 & 44.25 & 0.94 \\
\hline Total & 1914231 & 100.00 & 35.72 & 2.00 & 10.88 & 19.74 & 30.31 & 1.35 \\
\hline
\end{tabular}

23. Since the 1990s, business taxation has steadily declined. The statutory CIT rate declined across all countries in the sample from about 45\% in 1990 to about 30\% in 2014 (Figure 1). The effective tax rate (ETR) used in the current analysis - based on the total amount of taxes paid per dollar of profit - is declining since 1999. The marginal effective tax rate (METR), another measure calculated by the Oxford Centre for Business Taxation, has declined from almonst $25 \%$ in 1990 to about $15 \%$ in 2014 . This average decline in taxation, however, may hide large differences in the tax liabilities across firms.

4. The available accounting data do not allow distinguishing whether taxation is calculated on a cash or accrual bases. The paper adopts the convention that the tax base is profits in the same fiscal year. 
Figure 1. Declining trend of different measures of firm taxation

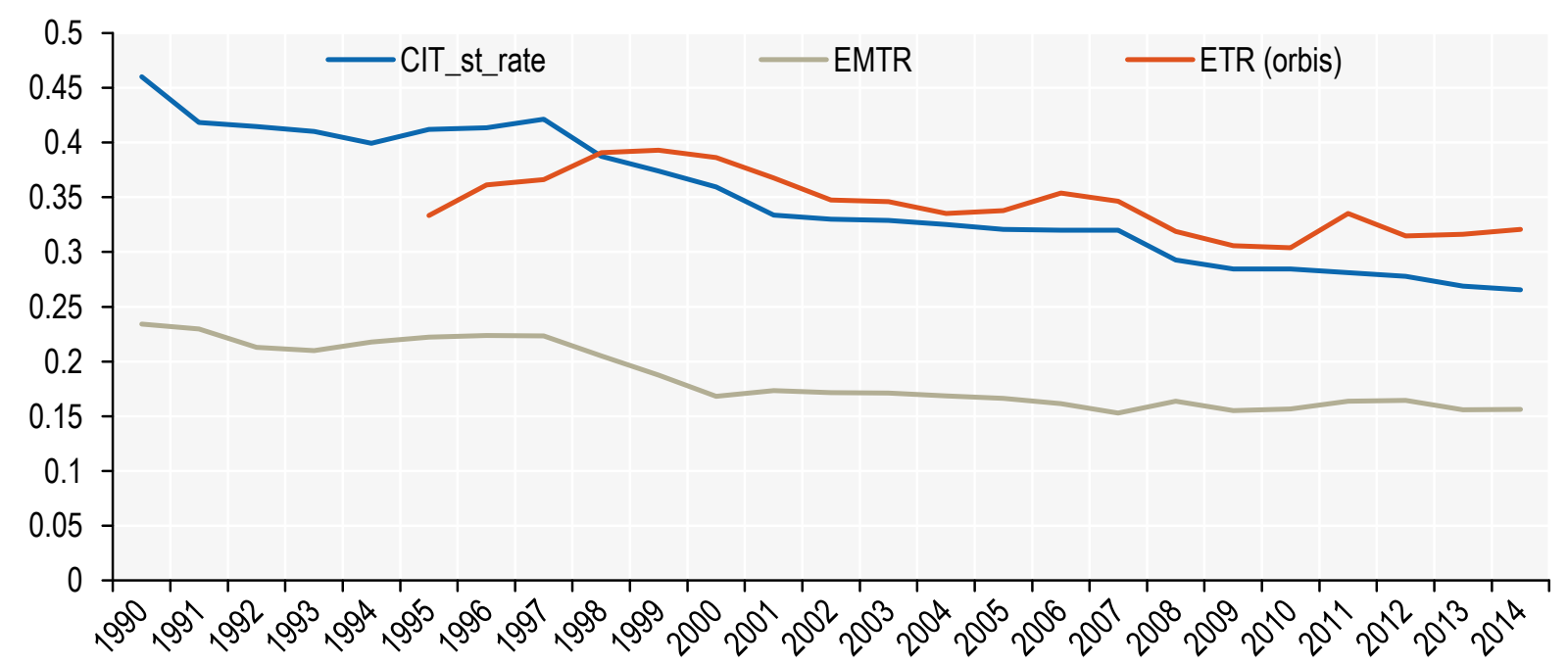

Note: Data refer to the average across the countries in the sample.

Source: Calculations based on ORBIS, OECD Revenue Statistics and Oxford University Centre for Business Taxation.

\subsection{The burden of taxation according to the productivity level}

24. Frontier firms are defined as the companies with the highest level of productivity in each sector and for each year. The baseline analysis is conducted using Gal's (2013) multifactor productivity indicators. Frontier firms are defined within each sector irrespective of their country of residence. For this reason the analysis refers to a global frontier as opposed to a national frontier. The share of firms selected defines the thickness of the frontier. In the analysis, the indicator refers to the top $5^{\text {th }}$ percentile of the distribution (and in a few cases to the top 100 firms). By contrast, bottom firms are defined as the bottom $25^{\text {th }}$ percentile of the productivity distribution. ${ }^{5}$

25. The thresholds for the top and bottom firms are defined for a fixed number of firms. In contrast with a constant share of firms in each year, the choice of a fixed number of firms ensures that it does not change over time as the sample expands. For instance, after ranking firms according to their productivity level the $5^{\text {th }}$ percentile is defined over the whole period considered, so that the number (not the identity) of firms that belong to the frontier does not change over time. This implies that the percentile of firms at the frontier is around the $5^{\text {th }}$ percentile, above in the years with a large sample, and below it in the years with a small sample.

26. The effective tax rate (average tax rate) paid by frontier firms is decreasing since 1999 (Table 2). By contrast, the effective tax rate of lagging firms has stabilised after a decrease in the period 1998-2004, resulting in an effective tax rate of frontier firms lower than that of the lagging firms since 2005. The gap has been widening since the global financial crisis (see Annex A for country specific trends).

5. Some of the firms with the lowest level of productivity meet the definition of zombie firms. They are old firms with difficulty to meet their interest payments. 
Figure 2. Evolution of the effective tax rate by productivity level

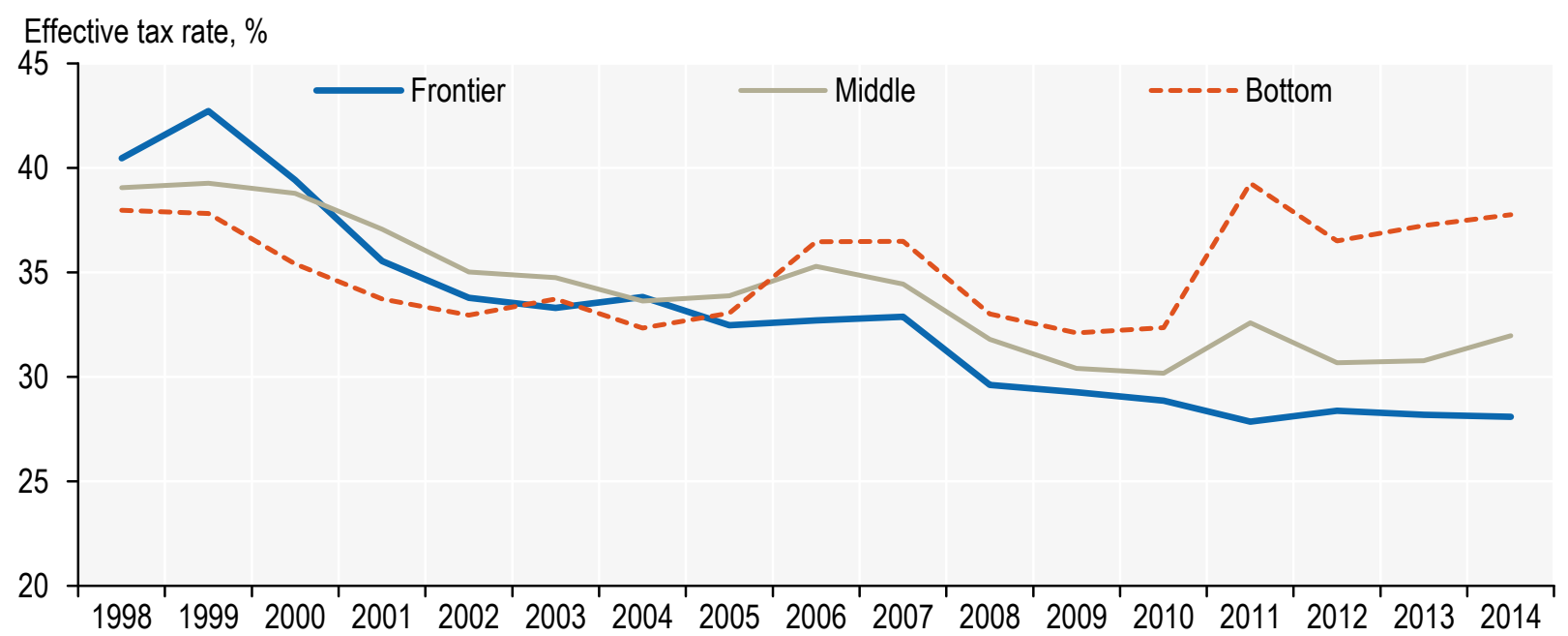

Note: Frontier firms are defined as firms in the top $5^{\text {th }}$ percentile of the multifactor productivity distribution for each industry-year. Bottom firms are firms in the bottom $25^{\text {th }}$ percentile of the productivity distribution for each industry-year. The middle group consists of the remaining firms.

Source: Calculations based on ORBIS database.

27. The decline in the effective tax rate faced by frontier firms happened in all sectors (Figure 3). It is interesting to note that differences between sectors have declined as well. In the period 1995-2005, manufacturing firms experienced a higher effective tax rate on average than firms in other sectors. After 2005, however, the difference between sectors is hardly statistically significant.

Figure 3. Effective tax rates of frontier firms, by industry

$(\mathrm{ETR}=$ taxation over taxable income $)$

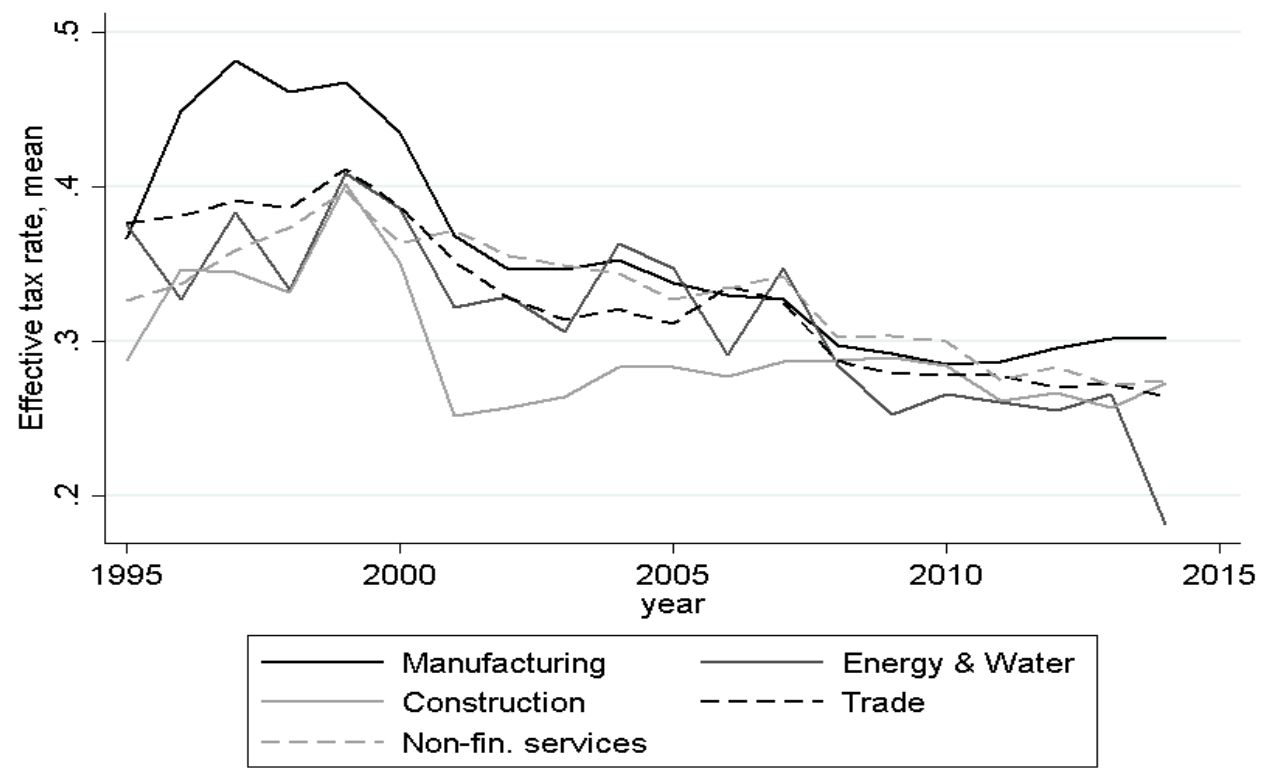

Note: Frontier firms are within the top $5^{\text {th }}$ percentile of the multifactor productivity distribution in each sector-year.

Source: Calculation based on the ORBIS database. 
28. The differential impact of taxation on firms at the frontier with respect to less productive firms is confirmed also when looking at the manufacturing and service sectors (Figure 4). The trend for the manufacturing sector reflects the aggregate trend, with a decline of the ETR for all firms until 2010 and then a sharp increase for the lagging ones. As regards firms operating in non-financial services, the main difference is the increasing ETR trend for bottom firms, i.e., the less productive ones. In both sectors, however, the trend of frontier and lagging firms starts diverging between 2005 and 2010, with an increasing tax gap between frontier and lagging firms.

Figure 4. Effective taxation in the manufacturing and service sectors

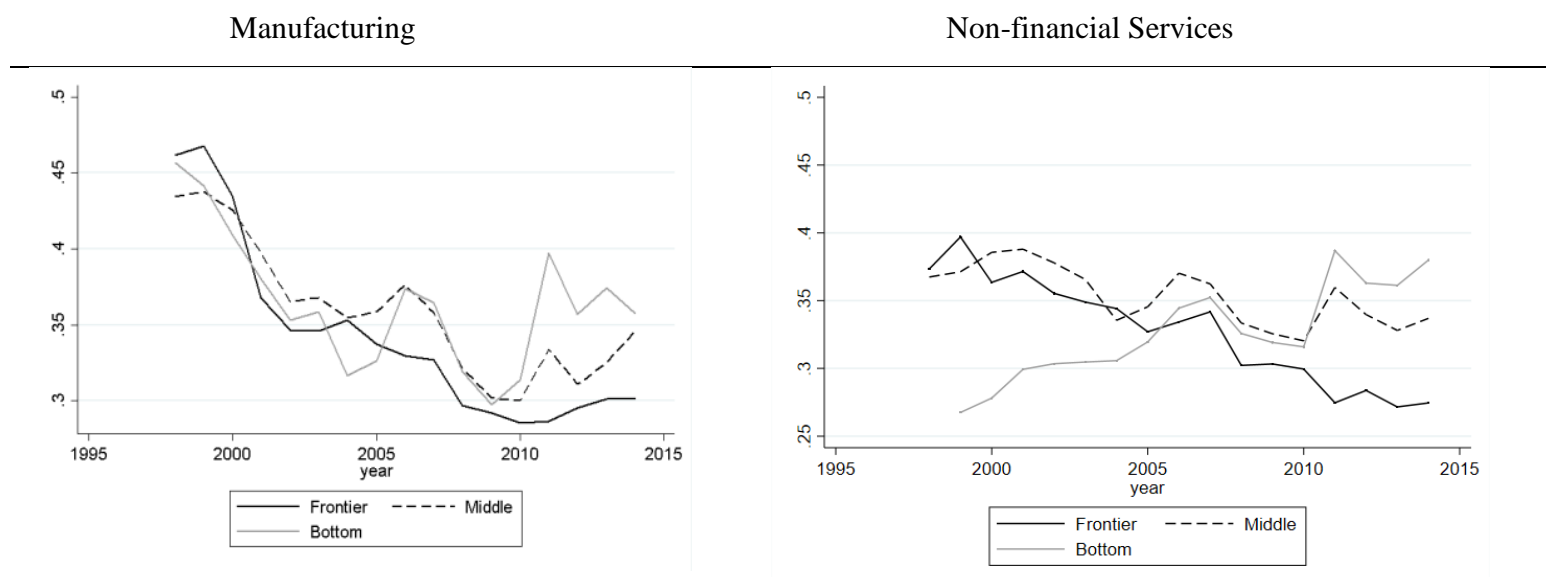

Note: Frontier firms are defined as firms in the top $5^{\text {th }}$ percentile of the multifactor productivity distribution for each industry-year. Bottom firms are firms in the bottom $25^{\text {th }}$ percentile of the productivity distribution for each industry-year. The middle group consists of the remaining firms.

Source: Calculations based on ORBIS database.

\section{Empirical analysis}

29. The empirical analysis looks first at the correlation between the effective tax rate and multifactor productivity, testing its robustness to country, time and sector fixed effects. A priori, the causal relation can go in both directions. Higher productivity may lead to lower effective taxation as well as lower effective taxation may lead to higher productivity.

30. In order to investigate the role of taxation for the catching-up potentials of firms, we investigate the hypotheis that the causal relation goes from high taxation to low multifactor productivity. The analysis, therefore, is conducted using an instrumental variable approach. The effective tax rate is instrumented with its own lagged values (one and two years) as tax liability in the previous years should affect today's productivity, and the CIT statutory rate, as it affects ETR but it is unlikely to be determined by the firm's level of productivity.

31. All regressions include country and time fixed effects as well as industry fixed effects. Country and time fixed effects control for events that affect the productivity of all firms or the tax liability in a specific country in a given year. Industry fixed effects are introduced to control for the possibility that the tax system treats sectors in different ways. This is the case for instance of environmental taxation, which affects manufacturing more than the service sector. 
32. The sample is restricted to firms with a positive tax liability. This reduces measurement errors and the impact of differences in loss carry forward rules across countries. The latter is particularly important because it is not possible to distinguish the source of tax liability, thus a lower tax liability could be the result of previous year(s) losses.

\subsection{Differences in the tax burden across firms}

33. The equation below is used to detect the presence of significant differences in a systematic way. The suffixes $i, j, s, t$ represent information on firm $i$ in country $j$, sector $s$, and year $t$.

$$
E T R_{i j s t}=c+\beta_{1} \text { Top }_{i j s t}+\beta_{2} \text { Bot }_{i j s t}+\beta_{3} A g e_{i j s t}+\beta_{4} \operatorname{lnEmp} p_{i j s t}+\eta_{j} * y_{t}+i_{s}+\epsilon_{i j s t}
$$

34. ETR represents the effective tax rate, Top is a dummy that is 1 if the firm is at the sectoral frontier; Bot is a dummy that is 1 if the firm is in the bottom $25^{\text {th }}$ percentile of the distribution. In a variant, Top and Bottom are replaced with MFP. Age and Emp are continuous variables that indicate the number of years a firm is active and the number of employees, respectively. Real value added also enters the equation in a variant. Finally, country and year fixed effects and industry fixed effects are included. The standard error is robust to heteroskedasticity.

35. Table 2 shows that the effective average tax rate:

- is negatively correlated with the level of multifactor productivity;

- is significantly lower for frontier than other firms: being at the frontier results in a 3 percentage point lower effective average tax rate as compared to the population of firms;

- increases with firms' age and size (measured by employment).

36. These results are robust to country-specific time trends that may affect the amount of taxes that firms pay and their industrial sector. Therefore, the estimated lower tax burden of frontier firms is net of any country-specific tax reform and industry-specific shocks that might have affected the rate. 
Table 2. Effective tax rate of frontier versus lagging firms

Dependent variable: effective average tax rate (taxation over taxable income)

\begin{tabular}{|c|c|c|c|c|}
\hline & (1) & (2) & (3) & (4) \\
\hline \multirow[t]{2}{*}{ MFP } & $-0.001^{* * *}$ & & & \\
\hline & $(0.000)$ & & & \\
\hline \multirow[t]{2}{*}{ Frontier } & & $-0.029^{* * *}$ & $-0.030^{* \star *}$ & $-0.021^{* * \star}$ \\
\hline & & $(0.001)$ & $(0.001)$ & $(0.001)$ \\
\hline \multirow[t]{2}{*}{ Bottom } & & & $0.008^{\star * *}$ & $-0.001^{*}$ \\
\hline & & & $(0.001)$ & $(0.001)$ \\
\hline \multirow[t]{2}{*}{ Age (category) } & & & $0.003^{* * *}$ & $0.003^{* * *}$ \\
\hline & & & $(0.000)$ & $(0.000)$ \\
\hline \multirow[t]{2}{*}{ Employees (log) } & & & $0.001^{* * *}$ & $0.012^{* * *}$ \\
\hline & & & $(0.000)$ & $(0.000)$ \\
\hline \multirow[t]{2}{*}{ Real value added (log) } & & & & $-0.012^{\star \star \star}$ \\
\hline & & & & $(0.000)$ \\
\hline \multirow[t]{2}{*}{ Constant } & $0.395^{\star \star *}$ & $0.368^{\star \star *}$ & $0.353^{* * *}$ & $0.500^{\star * *}$ \\
\hline & $(0.055)$ & $(0.010)$ & $(0.010)$ & $(0.011)$ \\
\hline Obs. & 1739954 & 1736606 & 1730398 & 1643461 \\
\hline Country*year fixed effects & YES & YES & YES & YES \\
\hline Sector fixed effects & YES & YES & YES & YES \\
\hline
\end{tabular}

Note: Robust standard errors in parenthesis. All models include country and year fixed effects and industry fixed effects. Age category consists of young (less than 5 years old), mature (between 5 and 10) and old (more than 10 years old) firms, with 1 being young firms. Employment is expressed as the natural logarithm of the number of employees in the company. The analysis is restricted to firms with more than 20 employees.

37. Differences in taxation are more pronounced in the manufacturing sector than in non-financial services (Table 3). This could be due to the smaller difference in the nonfinancial service sector between the frontier firms and the rest. Nevertheless, the tax gap between the frontier and other firms is statistically significant for all industries (except energy and water). As regards the bottom of the distribution, Table 3 shows that, in the full sample, firms at the bottom tend to pay a higher ETR than firms in the middle of the distribution, indicating that the ETR is monotonically correlated with the level of productivity - i.e. it decreases with productivity or sales volumes. This tendency is confirmed for the sub-sample of manufacturing firms but not for firms in the trade and non-financial service sectors, where firms at the top and bottom of the productivity distribution pay a lower ETR than firms in the middle of the distribution. Although firms at the productivity frontier pay a lower ETR in all sectors, the results seem to be mainly driven by the manufacturing sector. 
Table 3. Effective tax rate of frontier versus lagging firms by sector

Dependent variable: effective average tax rate (= taxation over taxable income)

\begin{tabular}{|c|c|c|c|c|c|c|c|}
\hline & \multirow{2}{*}{ Full sample } & \multirow{2}{*}{ Full sample } & \multicolumn{5}{|c|}{ Sectors } \\
\hline & & & Manufacturing & Energy \& water & Construction & Trade & Non-fin services \\
\hline \multirow[t]{2}{*}{ Frontier } & $-0.030^{* * *}$ & $-0.021^{* * *}$ & $-0.019^{\star \star *}$ & -0.006 & $-0.035^{\star \star \star}$ & $-0.023^{\star * *}$ & $-0.011^{\star \star *}$ \\
\hline & $(0.001)$ & $(0.001)$ & $(0.001)$ & $(0.006)$ & $(0.003)$ & $(0.002)$ & $(0.001)$ \\
\hline \multirow[t]{2}{*}{ Bottom } & $0.008^{\star \star \star}$ & $-0.001^{*}$ & $0.005^{\star \star \star}$ & $-0.019^{\star * *}$ & -0.001 & $-0.005^{\star \star \star}$ & $-0.006^{\star * *}$ \\
\hline & $(0.001)$ & $(0.001)$ & $(0.001)$ & $(0.004)$ & $(0.002)$ & $(0.001)$ & $(0.001)$ \\
\hline \multirow[t]{2}{*}{ Age } & $0.003^{* \star *}$ & $0.003^{* \star *}$ & $0.009^{* \star *}$ & $0.007^{* \star *}$ & $0.001^{*}$ & $0.002^{* \star *}$ & $-0.001^{\star * \star}$ \\
\hline & $(0.000)$ & $(0.000)$ & $(0.000)$ & $(0.002)$ & $(0.001)$ & $(0.001)$ & $(0.000)$ \\
\hline \multirow[t]{2}{*}{ Employment } & $0.001^{* * *}$ & $0.012^{* \star *}$ & $0.022^{* * *}$ & $0.020^{* * *}$ & 0.001 & $0.011^{* * *}$ & $0.011^{* * *}$ \\
\hline & $(0.000)$ & $(0.000)$ & $(0.001)$ & $(0.002)$ & $(0.001)$ & $(0.001)$ & $(0.000)$ \\
\hline \multirow[t]{2}{*}{ Value added } & & $-0.012^{\star \star \star}$ & $-0.026^{\star \star *}$ & $-0.021^{\star \star *}$ & $-0.003^{\star * *}$ & $-0.012^{\star \star \star}$ & $-0.008^{\star \star *}$ \\
\hline & & $(0.000)$ & $(0.000)$ & $(0.002)$ & $(0.001)$ & $(0.001)$ & $(0.000)$ \\
\hline \multirow[t]{2}{*}{ Constant } & $0.353^{\star * *}$ & $0.500^{\star * *}$ & $0.613^{\star * *}$ & $0.689^{* \star *}$ & $0.280^{\star * *}$ & $0.488^{* * *}$ & $0.473^{* * *}$ \\
\hline & $(0.010)$ & $(0.011)$ & $(0.019)$ & $(0.027)$ & $(0.060)$ & $(0.027)$ & $(0.020)$ \\
\hline Obs & 1730398 & 1643461 & 608819 & 33848 & 178078 & 327274 & 495442 \\
\hline \multicolumn{8}{|l|}{ Fixed effects: } \\
\hline Country*year & YES & YES & YES & YES & YES & YES & YES \\
\hline Sector & YES & YES & NO & NO & NO & NO & NO \\
\hline
\end{tabular}

Note: Frontier is a dummy that assumes value 1 if the firm is among the top 5\% in terms of MFP; similarly Bottom is a dummy that assumes value 1 if the firm is among the bottom $25 \%$ of the distribution of MFP. Age represents the years of activity of the company; Employment is the log of the number of employees; and Value added is the log of real value added.

38. For the ETR of frontier firms to be lower than for lagging firms, it must be that either the numerator (amount of taxation) is lower or the denominator (profits) is higher. Lower tax liability for given profits could reflect a lower amount of taxes paid on a tax base that does not affect the definition of profits; indeed, the tax liability is the aggregate value of all taxes the firm pays on different tax bases (for instance, property and land taxes on plants and other firms' facilities). Another possibility is that a different combination of inputs used to generate the same amount of profit leads to a lower tax liability. For instance, firms could switch to activities (or investments) that are taxed at lower rates or benefit from more favourable depreciation rules, like green technologies or intangible capital.

39. As regards innovation activities, which enjoy favourable tax treatment in most countries (Appelt, et al., 2016), a look at the evolution of the ratio of intangible fixed assets $^{6}$ of frontier firms with respect to the rest of firms, shows that frontier firms tend to have a higher ratio, i.e. they tend to have a higher share of intangible capital. Figure 5 shows that the trend is similar for all firms until 2005 when the trend of lagging firms started to diverge from the frontier. This divergence in the composition of capital is simultaneous with the emergence of the tax gap (Figure 5). No specific event that could explain the switch could be identified in 2005. In fact, the declining ETR trend for frontier

6. Intangible assets constist of assets without physical matter such as patents, franchises, copyrights, software and company goodwill, and include spending related to training, research and development. 
firms is quite constant, as well as the increase in the share of intangibles, reflecting longterm trends.

Figure 5. Share of intangible capital, difference between frontier and lagging firms

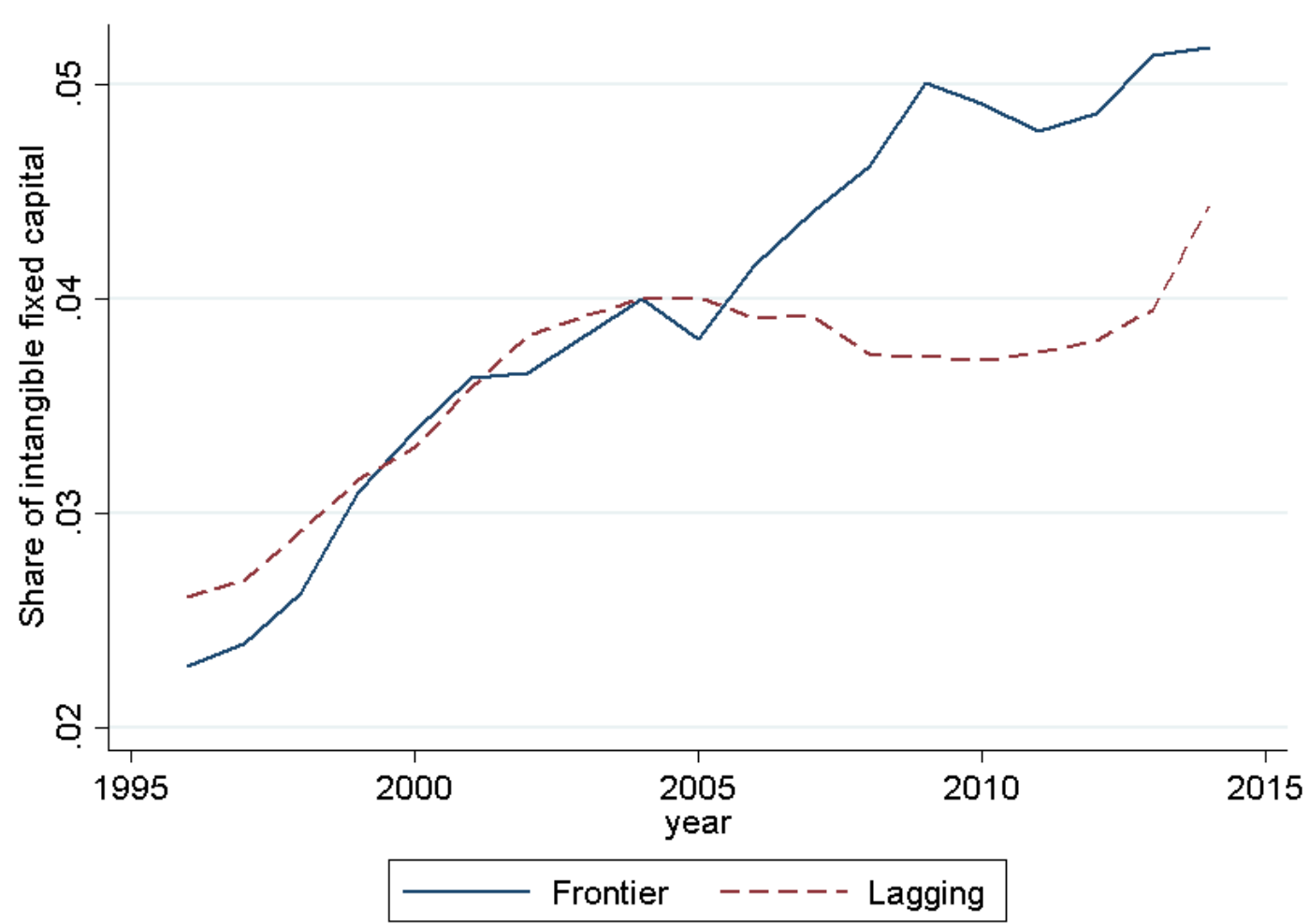

Source: Calculation based on ORBIS database.

40. The difference between the mean of the two groups, namely frontier and lagging firms, is reported in Table 4, which shows that the difference is statistically significant for the manufacturing sector but not for the non-financial service sector. Therefore, the different composition of capital could explain the lower tax burden only for firms in the manufacturing sector, which is more capital-intensive than services. The trend in the composition of capital between frontier and lagging firms confirms that this is mostly a manufacturing phenomenon (Figure 6), although in the service sector an increasing trend in the share of intangibles for frontier firms is also evident, but there is a plateau since 2002 for the lagging firms. 
Table 4. Tangible fixed-capital ratio, mean difference test

Difference between the mean tangible fixed-capital ratio of frontier firms and lagging firms.

\begin{tabular}{lcccccc}
\hline \multicolumn{1}{c}{ Group } & Obs & Mean & Std. Err. & Std. Dev. & [95\% Conf. interval] \\
\hline Manufacturing & & & & & \\
\hline Lagging & 868,345 & 0.814 & 0.000552 & 0.514291 & 0.81333 & 0.815493 \\
Frontier & 20,609 & 0.742 & 0.002529 & 0.363092 & 0.736905 & 0.74682 \\
Difference & & $0.073^{* * *}$ & 0.002589 & & 0.067475 & 0.077624 \\
\hline Non-financial services & & & & & 0.703233 & 0.70762 \\
\hline Lagging & 749,454 & 0.705 & 0.001119 & 0.968835 & 0.613873 & 0.982419 \\
Frontier & 19,473 & 0.798 & 0.094013 & 13.11905 & -0.27701 & 0.091566 \\
Difference & & -0.093 & 0.094019 & & & \\
\hline
\end{tabular}

Figure 6. Share of intangible capital in manufacturing and non-financial services

Manufacturing

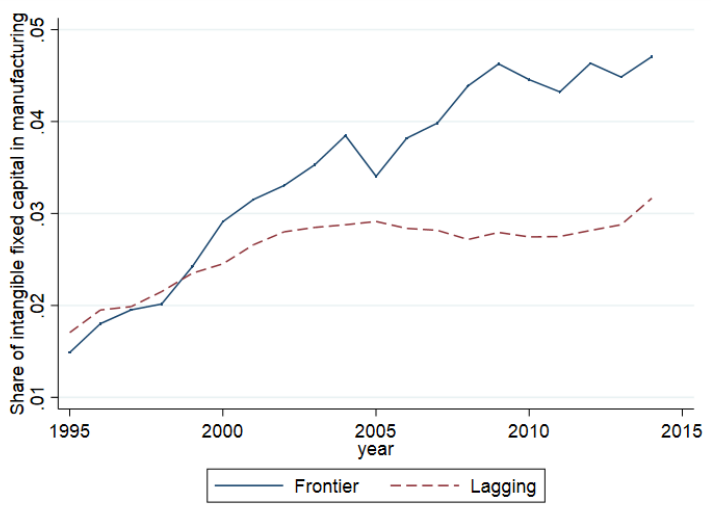

Non-financial services

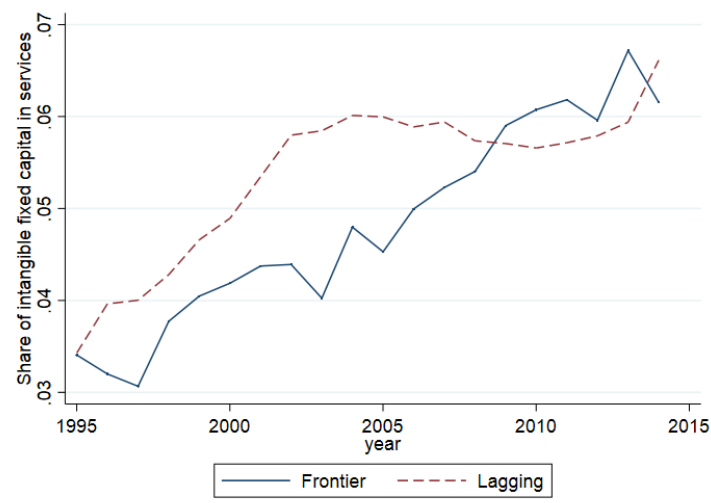

Source: Calculations based on ORBIS database.

41. In this setting, the presence of a larger share of intangible assets cannot be linked to profit shifting practices: it rather represents an indicator suggesting that tax deductions on research activities (e.g., patent boxes) encourage more accumulation of intangible capital. Recent research suggests a change in the composition of government incentives to R\&D towards tax deductions (Appelt, et al., 2016).

42. Another difference between frontier and lagging firms that could contribute to the tax gap is managerial capacity, which can be proxied by the difference between listed and non-listed firms or by the size of firms or their productivity. Under the assumption that frontier firms are better managed than less productive firms, it could be argued that superior managerial capacities leads to a more efficient tax strategy. For instance, the management of frontier firms could switch to greener technologies or more intangible capital faster without losing productivity (indeed, increasing it) or exploit tax discounts. These features should not depend on being a MNE.

43. Finally, previous work shows that frontier firms consist mainly of multinational firms (Andrews, et al., 2015), and that firms with stronger international ties engage in tax planning, by shifting profits abroad (Sorbe \& Johansson, 2017). This type of tax avoidance, however, cannot be the source of the results. The tax base registered in firms' 
accounts is already net of any tax planning action. If a firm decides to shift profits abroad, the resulting operating profit is lower; therefore, both numerator and denominator are smaller. What the analysis highlights is the possibility for MNEs to exploit mismatches between tax systems and enjoy preferential treatment (Johansson, et al., 2017). Furthermore, Dyreng et al. (2017) show that for U.S. firms the effective tax rate of multinational firms has decreased at the same pace as that of domestic firms over the period 1998-2012, indicating that the lower effective tax rate is not due to being a multinational firm.

44. To sum up, frontier firms' increasing use of intangible capital could be among the factors that drive the productivity and tax gaps. It remains to be investigated why lagging firms do not follow frontier ones in this process of dematerialisation, which seems associated with both higher productivity and lower taxation.

\subsection{ETR and firm productivity}

45. After showing that frontier firms pay a lower effective tax rate than the rest and that this is correlated with the increasing use of intantigible fixed assets by frontier firms, the analysis looks at whether taxation represents an obstacle to productivity diffusion.

46. Taxation, demand and access to credit affect the incentive and possibility of firms to invest. The investment can be in physical capital (e.g. new machinery), human capital (e.g. training and hiring) or R\&D. Acquiring new and more modern machinery and introducing innovative production processes is crucial for lagging firms to catch up with the productivity frontier. In this setting, the tax liability can prevent firms from investing, either because:

- it reduces the available resources to invest - cash flow constraints;

- it reduces the net return on the investment.

47. The empirical analysis considers a reduced-form model of the relationship between taxation and productivity in which the log of multifactor productivity, is regressed on firms' tax liability per dollar earned:

$$
M F P_{i j s t}=c+\beta_{1} E T R_{i j s t}+\beta_{2} X_{i j s t}+\left(\eta_{j} * y_{t}\right)+\iota_{s}+\epsilon_{i j s t}
$$

where ETR represents the effective tax rate of firm $i$ in country $j$, sector $s$, and time $t$; X is a set of control variables which include the age of the firm, its size in terms of employees and in terms of value added, the share of fixed assets, and whether the firm is listed. A country-year fixed effect is introduced to account for specific country characteristics that may lead to higher productivity in specific years: this reduces the risk of omitted variables bias. The sector fixed effect is included because some sectors are more productive than others. In order to assess whether a different pattern exists for firms at the frontier with respect to the rest of the distribution, the analysis is separately conducted for the sub-sample of lagging firms (i.e. all firms but the frontier).

48. In order to empirically assess the influence of effective taxation and its interaction with firms' characteristics and framework conditions have on multifactor productivity, the analysis is conducted using an instrumental variable approach, where the effective tax rate is instrumented with its past value and the statutory corporate income tax rate. The latter instrument is quite effective, as it influences each firm's tax liability without being affected by firm level of productivity. 
49. The results of the estimation of the econometric model using a two-stage least square approach are presented in Table 5. The first two columns show results for the full sample, and the other columns display the results for three sub-sets of firms, the frontier, the middle and the bottom productivity group. The negative effect of the ETR on the level of MFP is robust to the estimation with different instruments. When looking at subsamples it appears the the negative effect decreases with the level of productivity. It is smaller, albeit statistically significant, for frontier firms and largest for the firms at the bottom of the productivity distribution.

50. The estimation results support the idea that part of the performance of frontier firms is due to their lower tax liability. Reducing the tax liability of firms in the middle of the productivity distribution can enhance their chances to catch-up. By contrast, for firms in the bottom of the distribution, lower taxation would not raise their productivity. Similar results are presented by Gemmell et al. (forthcoming), who find in a sample of European firms over the period 1995-2005 that increasing the statutory corporate income tax rate negatively affects the speed of convergence.

Table 5. Effective taxation reduces multifactor productivity

\begin{tabular}{|c|c|c|c|c|c|}
\hline & (1) & (2) & (3) & (4) & (5) \\
\hline & Full & Full & Frontier & Middle & Bottom \\
\hline \multirow[t]{2}{*}{ ETR } & $-0.668^{* * *}$ & $-0.660^{* * *}$ & $-0.097^{\star * *}$ & $-0.100^{* * *}$ & $-0.548^{* * *}$ \\
\hline & $(0.054)$ & $(0.054)$ & $(0.034)$ & $(0.020)$ & $(0.207)$ \\
\hline \multirow[t]{2}{*}{ Age of firms } & $0.004^{* * *}$ & $0.004^{* \star *}$ & $0.000^{\star \star \star}$ & $0.001^{* * *}$ & 0.001 \\
\hline & $(0.000)$ & $(0.000)$ & $(0.000)$ & $(0.000)$ & $(0.001)$ \\
\hline \multirow[t]{2}{*}{ Employment } & $-0.000^{* \star *}$ & $-0.000^{\star \star \star}$ & $-0.000^{* * *}$ & $-0.000^{* * *}$ & $-0.000^{* * *}$ \\
\hline & $(0.000)$ & $(0.000)$ & $(0.000)$ & $(0.000)$ & $(0.000)$ \\
\hline \multirow[t]{2}{*}{ Turnover } & $0.000^{* * *}$ & $0.000^{* \star *}$ & $0.000^{* *}$ & $0.000^{* * *}$ & $0.000^{* * *}$ \\
\hline & $(0.000)$ & $(0.000)$ & $(0.000)$ & $(0.000)$ & $(0.000)$ \\
\hline \multirow[t]{2}{*}{ Fixed assets } & $0.000^{\star \star *}$ & $0.000^{\star \star *}$ & $0.000^{\star \star *}$ & $0.000^{\star \star *}$ & $-0.000^{* \star *}$ \\
\hline & $(0.000)$ & $(0.000)$ & $(0.000)$ & $(0.000)$ & $(0.000)$ \\
\hline \multirow[t]{2}{*}{ Listed } & $-0.400^{* * *}$ & $-0.400^{* * *}$ & $-0.139^{\star \star *}$ & $-0.146^{* * *}$ & $0.325^{\star *}$ \\
\hline & $(0.025)$ & $(0.025)$ & $(0.007)$ & $(0.010)$ & $(0.131)$ \\
\hline \multirow[t]{2}{*}{ Constant } & $10.523^{\star \star \star}$ & $10.520^{\star \star \star}$ & $11.966^{\star \star *}$ & $9.802^{\star \star \star}$ & $-7.589^{\star \star *}$ \\
\hline & $(0.084)$ & $(0.084)$ & $(0.029)$ & $(0.032)$ & $(0.497)$ \\
\hline Obs. & 356652 & 356652 & 23759 & 266250 & 66643 \\
\hline $\begin{array}{l}\text { Fixed effects: } \\
\text { country, time, sectors }\end{array}$ & YES & YES & YES & YES & YES \\
\hline Instruments & Lagged ETR & $\begin{array}{l}\text { Lagged ETR and } \\
\text { CIT statutory rate }\end{array}$ & $\begin{array}{l}\text { Lagged ETR and } \\
\text { CIT statutory rate }\end{array}$ & $\begin{array}{l}\text { Lagged ETR and } \\
\text { CIT statutory rate }\end{array}$ & $\begin{array}{l}\text { Lagged ETR and } \\
\text { CIT statutory rate }\end{array}$ \\
\hline
\end{tabular}

Note: Robust standard errors in parenthesis. The two-stage least squares estimator is used for the instrumental variable regressions. Frontier consists of firms in the top $5^{\text {th }}$ percentile of the productivity distribution; bottom consists of firms in the bottom $25^{\text {th }}$ percentile of the productivity distribution; Middle is the residual category. Source: Regressions based on ORBIS data.

51. Effective taxation may interact with some firm characteristics and reduce the capacity to acquire innovative technologies. This might be the case if a combination of high taxation, low cash availability and credit constraints co-exist. The idea is that taxation would affect firms with lower cash flow more. The results of the empirical model with an interaction term between effective taxation and cash flow show that the availability of cash signifincatly reduces the negative effect of the ETR (Table 6, column 1). This effect seems to be mainly driven by firms in the middle of the productivity distribution (Table 6 , 
columns 2-4). This is revealing of the difficulty of firms to catch up with the frontier because of a lack of resources. By contrast, the interaction with the trend in sales, which represents a source of cash for firms, does not seem to affect the relationship between ETR and productivity.

Table 6. Cash constraints worsen the effect of ETR on MFP

Dependent variable: log of MFP per worker

\begin{tabular}{|c|c|c|c|c|c|c|c|c|}
\hline & (1) & $(2)$ & (3) & (4) & (5) & $(6)$ & $(7)$ & (8) \\
\hline & Full & Frontier & Middle & Bottom & Full & Frontier & Middle & Bottom \\
\hline \multirow[t]{2}{*}{ ETR } & $-0.997^{* * *}$ & $-0.100^{* \star}$ & $-0.188^{* * *}$ & $-0.610^{* \star}$ & $-0.883^{\star * *}$ & $-0.106^{* *}$ & $-0.176^{\star * *}$ & -0.415 \\
\hline & $(0.078)$ & $(0.051)$ & $(0.020)$ & $(0.308)$ & $(0.077)$ & $(0.049)$ & $(0.020)$ & $(0.303)$ \\
\hline \multirow[t]{2}{*}{ Interaction cash } & $2.766^{\star \star \star}$ & -0.235 & $0.592^{* \star *}$ & -0.041 & & & & \\
\hline & $(0.342)$ & $(0.237)$ & $(0.086)$ & $(1.343)$ & & & & \\
\hline \multirow[t]{2}{*}{ Cash } & $-0.593^{\star * *}$ & 0.079 & $-0.066^{* *}$ & $-2.129^{\star \star \star}$ & & & & \\
\hline & $(0.118)$ & $(0.077)$ & $(0.030)$ & $(0.452)$ & & & & \\
\hline \multirow[t]{2}{*}{ Age of firm } & $0.004^{* \star *}$ & $0.001^{* * *}$ & $0.001^{* * *}$ & 0.002 & $0.005^{\star \star *}$ & $0.000^{* *}$ & $0.001^{* * *}$ & -0.000 \\
\hline & $(0.000)$ & $(0.000)$ & $(0.000)$ & $(0.001)$ & $(0.000)$ & $(0.000)$ & $(0.000)$ & $(0.001)$ \\
\hline \multirow[t]{2}{*}{ Employees } & $-0.000^{* * *}$ & $-0.000^{* * *}$ & $-0.000^{* * *}$ & $-0.000^{\star * *}$ & $-0.000^{* * *}$ & $-0.000^{* * *}$ & $-0.000^{* *}$ & $-0.000^{* * *}$ \\
\hline & $(0.000)$ & $(0.000)$ & $(0.000)$ & $(0.000)$ & $(0.000)$ & $(0.000)$ & $(0.000)$ & $(0.000)$ \\
\hline \multirow[t]{2}{*}{ Turnover } & $0.000^{* * *}$ & 0.000 & $0.000^{* * *}$ & $0.000^{\star \star \star}$ & $0.000^{* * *}$ & -0.000 & 0.000 & $0.000^{\star * *}$ \\
\hline & $(0.000)$ & $(0.000)$ & $(0.000)$ & $(0.000)$ & $(0.000)$ & $(0.000)$ & $(0.000)$ & $(0.000)$ \\
\hline \multirow[t]{2}{*}{ Fixed assets } & $0.000^{* * *}$ & $0.000^{* * *}$ & $0.000^{* * *}$ & $-0.000^{* * *}$ & $0.000^{\star \star \star}$ & $0.000^{* * *}$ & $0.000^{* * *}$ & -0.000 \\
\hline & $(0.000)$ & $(0.000)$ & $(0.000)$ & $(0.000)$ & $(0.000)$ & $(0.000)$ & $(0.000)$ & $(0.000)$ \\
\hline \multirow[t]{2}{*}{ Listed } & $-0.408^{* * *}$ & $-0.142^{\star * \star}$ & $-0.145^{\star * \star}$ & $0.326^{\star *}$ & $-0.338^{* * *}$ & $-0.131^{* * *}$ & $-0.185^{\star * *}$ & $2.217^{\star \star *}$ \\
\hline & $(0.028)$ & $(0.008)$ & $(0.008)$ & $(0.150)$ & $(0.039)$ & $(0.010)$ & $(0.011)$ & $(0.248)$ \\
\hline \multirow[t]{2}{*}{ Ineraction sales growth } & & & & & 0.003 & $-0.111^{*}$ & 0.001 & 0.004 \\
\hline & & & & & $(0.005)$ & $(0.062)$ & $(0.001)$ & $(0.026)$ \\
\hline \multirow[t]{2}{*}{ Sales growth } & & & & & -0.001 & $0.042^{* *}$ & -0.000 & 0.003 \\
\hline & & & & & $(0.001)$ & $(0.019)$ & $(0.000)$ & $(0.006)$ \\
\hline \multirow[t]{2}{*}{ Constant } & $10.694^{* * *}$ & $11.999^{* * *}$ & $10.390^{* * *}$ & $-7.577^{\star * *}$ & $10.464^{\star \star *}$ & $11.966^{\star \star \star}$ & $10.507^{\star * *}$ & $-14.857^{\star \star \star}$ \\
\hline & $(0.096)$ & $(0.034)$ & $(0.027)$ & $(0.584)$ & $(0.126)$ & $(0.040)$ & $(0.034)$ & $(0.852)$ \\
\hline Obs. & 288232 & 19108 & 215673 & 53451 & 253569 & 15577 & 191782 & 46210 \\
\hline
\end{tabular}

Note: Robust standard errors in parenthesis. Country, year, and sector fixed effects are included. All models are estimated using the 1 and 2 year lagged value of ETR and the CIT statutory rate as instruments for ETR. Source: Calculations based on ORBIS database.

52. The possibility to access credit may be affected by the current debt position of firms. The interaction between taxation and the ratio between long-term debt and total assets, as well as the interaction with the solvency ratio (the capital available to cover current liabilities) provide interesting insights. Long-term debt reinforces the negative effect of taxation on MFP although it seems not to interact with taxation (Table 7, column 1). Also in the sub-samples there is no evidence of any significant interaction with taxation (Table 7, columns 2-4). By contrast, solvency does not have a direct impact on MFP (Table 7, column 5), but affect the way in which taxation influences MFP. The more solvent is a firm the lower the negative effect of taxation (the coefficient associated with the interaction term in column 5 is positive and statistically significant). Interestingly this effect seems to be driven by firms in the middle of the productivity distribution, thus representing a bottleneck for catching up. Higher taxation therefore appears to be more harmful when a firm faces financial constraints, presumably because a constrained firm cannot substitute external funds for the reduction of cash-flow due to higher taxation. 
Table 7. Solvency reduces the negative effect of ETR on productivity

Dependent variable: Log of MFP per worker

\begin{tabular}{|c|c|c|c|c|c|c|c|c|}
\hline & (1) & (2) & (3) & (4) & (5) & (6) & (7) & (8) \\
\hline & Full & Frontier & Middle & Bottom & Full & Frontier & Middle & Bottom \\
\hline ETR & $-0.787^{\star \star \star}$ & $-0.133^{* *}$ & $-0.156^{* \star *}$ & $-0.711^{\star *}$ & $-0.895^{\star \star \star}$ & 0.054 & $-0.170^{\star \star \star}$ & -0.252 \\
\hline \multirow{3}{*}{ Interaction.Debt/assets } & $(0.081)$ & $(0.053)$ & $(0.021)$ & $(0.323)$ & $(0.080)$ & $(0.055)$ & $(0.021)$ & $(0.317)$ \\
\hline & -0.441 & 0.003 & 0.072 & $1.999^{*}$ & & & & \\
\hline & (0.322) & $(0.221)$ & $(0.086)$ & (1.081) & & & & \\
\hline \multirow[t]{2}{*}{ Debt/assets } & $-0.794^{* * *}$ & $0.306^{* * *}$ & $-0.433^{* * *}$ & $0.844^{* *}$ & & & & \\
\hline & $(0.105)$ & $(0.068)$ & $(0.029)$ & $(0.333)$ & & & & \\
\hline \multirow[t]{2}{*}{ Age of firm } & $0.004^{* \star *}$ & $0.000^{* * *}$ & $0.001^{* * *}$ & $0.002^{*}$ & $0.003^{* * *}$ & $0.000^{* * *}$ & $0.000^{* \star *}$ & $0.004^{\star \star *}$ \\
\hline & $(0.000)$ & $(0.000)$ & $(0.000)$ & $(0.001)$ & $(0.000)$ & $(0.000)$ & $(0.000)$ & $(0.001)$ \\
\hline \multirow[t]{2}{*}{ Employees } & $-0.000^{* \star *}$ & $-0.000^{* \star *}$ & $-0.000^{* * *}$ & $-0.000^{* * *}$ & $-0.000^{* * *}$ & $-0.000^{* * *}$ & $-0.000^{* * *}$ & $-0.000^{\star \star *}$ \\
\hline & $(0.000)$ & $(0.000)$ & $(0.000)$ & $(0.000)$ & $(0.000)$ & $(0.000)$ & $(0.000)$ & $(0.000)$ \\
\hline \multirow[t]{2}{*}{ Turnover } & $0.000^{* * *}$ & $0.000^{* *}$ & $0.000^{* * *}$ & $0.000^{\star * *}$ & $0.000^{* * *}$ & 0.000 & $0.000^{\star \star *}$ & $0.000^{* * *}$ \\
\hline & $(0.000)$ & $(0.000)$ & $(0.000)$ & $(0.000)$ & $(0.000)$ & $(0.000)$ & $(0.000)$ & $(0.000)$ \\
\hline \multirow[t]{2}{*}{ Fixed assets } & $0.000^{* \star *}$ & $0.000^{* * *}$ & $0.000^{* * *}$ & $-0.000^{* \star *}$ & $0.000^{* \star *}$ & $0.000^{\star \star *}$ & $0.000^{* \star *}$ & $-0.000^{\star \star *}$ \\
\hline & $(0.000)$ & $(0.000)$ & $(0.000)$ & $(0.000)$ & $(0.000)$ & $(0.000)$ & $(0.000)$ & $(0.000)$ \\
\hline \multirow[t]{2}{*}{ Listed } & $-0.428^{* * *}$ & $-0.129^{\star \star *}$ & $-0.152^{* * *}$ & $0.331^{* *}$ & $-0.386^{* * *}$ & $-0.140^{* * *}$ & $-0.141^{* \star *}$ & $0.245^{*}$ \\
\hline & $(0.028)$ & $(0.008)$ & $(0.008)$ & $(0.149)$ & $(0.028)$ & $(0.008)$ & $(0.008)$ & $(0.148)$ \\
\hline \multirow[t]{2}{*}{ Interaction solvency } & & & & & $1.065^{\star \star *}$ & $-0.657^{\star \star *}$ & $0.231^{* * *}$ & $-2.449^{\star \star *}$ \\
\hline & & & & & $(0.208)$ & $(0.140)$ & $(0.054)$ & $(0.752)$ \\
\hline \multirow[t]{2}{*}{ Solvency } & & & & & 0.018 & $0.255^{\star \star *}$ & -0.015 & -0.381 \\
\hline & & & & & $(0.071)$ & $(0.045)$ & $(0.019)$ & $(0.248)$ \\
\hline \multirow[t]{2}{*}{ Constant } & $10.827^{* * *}$ & $11.958^{* * *}$ & $10.455^{\star * *}$ & $-8.019^{\star \star \star}$ & $10.510^{* * *}$ & $11.937^{* * *}$ & $10.357^{\star \star *}$ & $-7.202^{\star \star \star}$ \\
\hline & $(0.097)$ & $(0.035)$ & $(0.027)$ & $(0.589)$ & $(0.097)$ & $(0.036)$ & $(0.027)$ & $(0.583)$ \\
\hline Obs. & 284505 & 18711 & 213043 & 52751 & 292269 & 19522 & 218498 & 54249 \\
\hline
\end{tabular}

Note: Robust standard errors in parenthesis. Country, year and sector fixed effects are included. All models are estimated using the 1 and 2 year lagged value of ETR and the CIT statutory rate as instruments for ETR. Source: Calculations based on ORBIS database.

53. Framework conditions like product market regulation (PMR) and employment protection legislation for regular contracts (EPL) may affect the opportunities of firms to catch up with the productivity frontier. The analysis, however, is less solid than in the previous cases because these indicators are not firm specific so that they are included in the regression only interacted with ETR (which is firm specific). Results suggest that PMR has no effect on the way in which taxation affects productivity. However, when looking at the sub-samples it seems to weakly reduce the negative impact of ETR for firms in the middle of the productivity distribution. This result, however, should be take with caution as the coefficient of the direct impact of ETR on MFP is no longer significant for frontier and bottom firms and loses significace for firms in the middle (Table 8, columns 2-4).

54. As regards employment protection legislation for regular contracts, the results are clearer. EPL accentuates the negative impact of taxation on MFP, a result that seems to be driven mainly by firms in the middle of the productivity distribution (Table 8, column 7). It represents an obstacle for firms to hire workers with more advanced technological skills, thus reducing the incentive to acquire such technologies - a computer and a computer expert are needed to improve productivity. 
Table 8. Taxation and market regulation

Dependent variable: $\log$ of MFP per worker

\begin{tabular}{|c|c|c|c|c|c|c|c|c|}
\hline & (1) & $(2)$ & (3) & (4) & (5) & $(6)$ & $(7)$ & (8) \\
\hline & Full & Frontier & Middle & Bottom & Full & Frontier & Middle & Bottom \\
\hline \multirow[t]{2}{*}{$\overline{E T R}$} & $-0.825^{\star \star \star}$ & 0.002 & $-0.105^{\star \star}$ & -0.426 & $-0.372^{\star \star \star}$ & $-0.158^{\star \star \star}$ & $-0.072^{\star \star \star}$ & $-0.848^{* *}$ \\
\hline & $(0.160)$ & $(0.100)$ & $(0.053)$ & $(0.597)$ & $(0.093)$ & $(0.052)$ & $(0.024)$ & $(0.363)$ \\
\hline \multirow[t]{2}{*}{ Interaction PMR } & 0.030 & $-0.245^{\star * *}$ & $0.120^{* *}$ & $-4.608^{\star \star *}$ & & & & \\
\hline & $(0.168)$ & $(0.085)$ & $(0.054)$ & $(0.762)$ & & & & \\
\hline \multirow[t]{2}{*}{ Age of firms } & $0.004^{* * *}$ & 0.000 & $0.001^{* * *}$ & $0.004^{*}$ & $0.004^{* * *}$ & $0.000^{* * *}$ & $0.000^{* * *}$ & $0.002^{* *}$ \\
\hline & $(0.001)$ & $(0.000)$ & $(0.000)$ & $(0.002)$ & $(0.000)$ & $(0.000)$ & $(0.000)$ & $(0.001)$ \\
\hline \multirow[t]{2}{*}{ Employees } & $-0.000^{* * *}$ & $-0.000^{* \star *}$ & $-0.000^{* *}$ & -0.000 & $-0.000^{* * *}$ & $-0.000^{* * *}$ & $-0.000^{* * *}$ & $-0.000^{* * *}$ \\
\hline & $(0.000)$ & $(0.000)$ & $(0.000)$ & $(0.000)$ & $(0.000)$ & $(0.000)$ & $(0.000)$ & $(0.000)$ \\
\hline \multirow[t]{2}{*}{ Turnover } & $0.000^{* * *}$ & 0.000 & $0.000^{* *}$ & $0.000^{* *}$ & $0.000^{* * *}$ & 0.000 & $0.000^{* * *}$ & $0.000^{* * *}$ \\
\hline & $(0.000)$ & $(0.000)$ & $(0.000)$ & $(0.000)$ & $(0.000)$ & $(0.000)$ & $(0.000)$ & $(0.000)$ \\
\hline \multirow[t]{2}{*}{ Fixed assets } & $0.000^{*}$ & $0.000^{* * *}$ & 0.000 & -0.000 & $0.000^{* * *}$ & $0.000^{\star * *}$ & $0.000^{* * *}$ & $-0.000^{* * *}$ \\
\hline & $(0.000)$ & $(0.000)$ & $(0.000)$ & $(0.000)$ & $(0.000)$ & $(0.000)$ & $(0.000)$ & $(0.000)$ \\
\hline \multirow[t]{2}{*}{ Listed } & $-0.367^{\star * *}$ & $-0.121^{* \star \star}$ & $-0.135^{\star \star *}$ & $0.753^{* *}$ & $-0.396^{* * *}$ & $-0.142^{\star \star *}$ & $-0.139^{* * *}$ & 0.220 \\
\hline & $(0.060)$ & $(0.017)$ & $(0.021)$ & $(0.324)$ & $(0.028)$ & $(0.008)$ & $(0.008)$ & $(0.148)$ \\
\hline \multirow[t]{2}{*}{ Interaction EPL } & & & & & $-2.051^{* * *}$ & 0.099 & $-0.314^{* * *}$ & 1.150 \\
\hline & & & & & $(0.228)$ & $(0.097)$ & $(0.060)$ & $(0.925)$ \\
\hline \multirow[t]{2}{*}{ Constant } & $10.573^{* * *}$ & $11.974^{\star * *}$ & $10.277^{\star * *}$ & $-7.561^{* * *}$ & $10.624^{* * *}$ & $12.019^{\star * *}$ & $10.356^{\star \star *}$ & $-7.380^{* * *}$ \\
\hline & (0.199) & $(0.069)$ & $(0.070)$ & (1.099) & $(0.097)$ & (0.034) & $(0.027)$ & $(0.579)$ \\
\hline Obs. & 65334 & 4535 & 48670 & 12129 & 278118 & 18417 & 206463 & 53238 \\
\hline
\end{tabular}

Note: Robust SE in parenthesis. Country, year, and sector fixed effects are included. All models are estimated using the 1 and 2 year lagged value of ETR and the CIT statutory rate as instruments for ETR. Both the PMR and EPL indicators are de-meaned.

Source: Calculations based on ORBIS database.

55. The interaction of taxation with EPL is mainly driven by firms with average productivity (middle), for which the negative impact of taxation is amplified by strict employment protection legislation. By contrast, for firms at the frontier, stricter EPL does not affect the impact of ETR. Most probably, firms at the productivity frontier have already an efficient mix of capital and labour, so that EPL is not binding.

56. The impact of taxation on the productivity of firms could also depend on the possibility to access foreign markets and integrate in global value chains (GVC). To capture this, two indicators are used. The first is the share of exports and imports over the country's GDP (Openness), which measures the amount of integration of the domestic economy with international markets and is also an indicator of global demand trends. The second considers legal and regulatory barriers to trade, including taxation and capital account restrictions (Free Trade). ${ }^{7}$ This indicator is particularly important because such barriers reduce the access to foreign markets regardless of the economic trend.

57. The estimation results reported in Table 9 show that taxation has a negative effect on the level of productivity also when including the two indicators of globalisation. The interaction term with trade openness, however, is not statistically significant (Column 1). It gains significance when looking at the three sub-groups of firms. In this case, however, the ETR loses significance, indicating (as in the case of market regulation) that the results are

7. This index is compiled by KOF Swiss Economic Institute (Gygli, et al., 2018). 


\section{4 | ECO/WKP(2018)23}

difficult to interpret. By contrast free trade significantly reduces the negative effect of taxation - i.e., the interaction term is positive and statistically significant (column 5).

Table 9. The interaction between trade openness and taxation

Dependent variable: $\log$ of MFP per worker

\begin{tabular}{|c|c|c|c|c|c|c|c|c|}
\hline & (1) & (2) & (3) & (4) & (5) & (6) & (7) & (8) \\
\hline & Full & Frontier & Midlle & Bottom & Full & Frontier & Middle & Bottom \\
\hline \multirow[t]{2}{*}{ ETR } & $-0.841^{* \star *}$ & 0.058 & $-0.143^{* *}$ & 0.622 & $-0.858^{\star \star \star \star}$ & $-0.159^{\star * \star}$ & $-0.170^{\star \star \star}$ & $-1.161^{* \star *}$ \\
\hline & $(0.168)$ & $(0.103)$ & $(0.057)$ & $(0.626)$ & $(0.079)$ & $(0.055)$ & $(0.021)$ & $(0.303)$ \\
\hline \multirow[t]{2}{*}{ Ineraction openness } & -0.519 & $2.535^{\star \star *}$ & $-1.096^{* *}$ & $41.803^{* * *}$ & & & & \\
\hline & $(1.726)$ & $(0.929)$ & $(0.528)$ & (8.242) & & & & \\
\hline \multirow[t]{2}{*}{ Age of firms } & $0.004^{\star * *}$ & 0.000 & $0.001^{* * *}$ & 0.004 & $0.004^{* * *}$ & $0.001^{* \star *}$ & $0.000^{* \star \star}$ & 0.001 \\
\hline & $(0.001)$ & $(0.000)$ & $(0.000)$ & $(0.002)$ & $(0.000)$ & $(0.000)$ & $(0.000)$ & $(0.001)$ \\
\hline \multirow[t]{2}{*}{ Employees } & $-0.000^{\star * \star}$ & $-0.000^{* *}$ & $-0.000^{* *}$ & -0.000 & $-0.000^{* * *}$ & $-0.000^{\star * \star}$ & $-0.000^{* * *}$ & $-0.000^{\star * *}$ \\
\hline & $(0.000)$ & $(0.000)$ & $(0.000)$ & $(0.000)$ & $(0.000)$ & $(0.000)$ & $(0.000)$ & $(0.000)$ \\
\hline \multirow[t]{2}{*}{ Turnover } & $0.000^{* * *}$ & 0.000 & $0.000^{* *}$ & $0.000^{\star *}$ & $0.000^{\star * *}$ & 0.000 & $0.000^{* * *}$ & $0.000^{* * *}$ \\
\hline & $(0.000)$ & $(0.000)$ & $(0.000)$ & $(0.000)$ & $(0.000)$ & $(0.000)$ & $(0.000)$ & $(0.000)$ \\
\hline \multirow[t]{2}{*}{ Fixed assets } & $0.000^{*}$ & $0.000^{* * *}$ & 0.000 & -0.000 & $0.000^{* * *}$ & $0.000^{* \star *}$ & $0.000^{* * *}$ & $-0.000^{* * *}$ \\
\hline & $(0.000)$ & $(0.000)$ & $(0.000)$ & $(0.000)$ & $(0.000)$ & $(0.000)$ & $(0.000)$ & $(0.000)$ \\
\hline \multirow[t]{2}{*}{ Listed } & $-0.366^{\star \star *}$ & $-0.127^{\star * \star}$ & $-0.132^{* * *}$ & $0.685^{\star \star}$ & $-0.403^{\star * *}$ & $-0.140^{\star * *}$ & $-0.139^{\star \star \star}$ & $0.290^{*}$ \\
\hline & $(0.060)$ & $(0.017)$ & $(0.021)$ & $(0.335)$ & $(0.029)$ & $(0.008)$ & $(0.008)$ & $(0.151)$ \\
\hline \multirow[t]{2}{*}{ Interaction free trade } & & & & & $3.320^{* * *}$ & 0.622 & $1.564^{* * *}$ & $-47.807^{* * *}$ \\
\hline & & & & & $(0.951)$ & $(0.772)$ & $(0.237)$ & (3.760) \\
\hline \multirow[t]{2}{*}{ Constant } & $10.590^{\star \star *}$ & $11.893^{\star \star \star}$ & $10.327^{\star \star \star}$ & $-9.651^{\text {** }}$ & $10.564^{\star \star *}$ & $11.999^{\star \star \star}$ & $10.319^{\star \star *}$ & $-5.347^{* * *}$ \\
\hline & $(0.197)$ & $(0.069)$ & $(0.070)$ & $(1.110)$ & $(0.101)$ & $(0.038)$ & $(0.027)$ & $(0.608)$ \\
\hline Obs. & 65334 & 4535 & 48670 & 12129 & 274946 & 18019 & 203960 & 52967 \\
\hline
\end{tabular}

Note: Robust standard errors in parenthesis. Country, year, and sector fixed effects are included. All models are estimated using the 1 and 2 year lagged value of ETR and the CIT statutory rate as instruments for ETR. Source: Calculations based on ORBIS database.

58. In this case, reducing de jure trade barriers seems to benefit mainly firms in the middle of the productivity distribution (column 6-8). The interaction term is positive and statistically significant only for the middle group, indicating that an increase in the indicator (i.e., a reduction of barriers) reduces the negative effect of ETR on this type of firms. 


\section{References}

Adalet McGowan, M., Andrews, D. \& Millot, V., 2017. Insovency regimes, zombie firms and capital reallocation, Paris: OECD Economics Department Working Papers, No. 54.

Andrews, D. \& Cingano, F., 2012. Public Policy and Allocation: Evidence from Firms in OECD Countries. OECD Economics Department Working Papers, Issue 996.

Andrews, D., Criscuolo, C. \& Gal, P., 2015. Frontier firms, technology diffusion and public policy: micro evidence from OECD firms, Paris: OECD Publishing.

Andrews, D., Criscuolo, C. \& Gal, P. N., 2016. The best versus the rest: the global productivity slowdown, divergence across firms and the role of public policy, Paris: OECD Publishing.

Appelt, S., Bajgar, M., Criscuolo, C. \& Galindo-Rueda, F., 2016. R\&D Tax Incentives: Evidence on design, incidence and impacts, Paris: OECD Science, Technology and Industry Policy Papers, No. 32.

Bloom, N. \& Van Reenen, J., 2010. Why do management practices differ across firms and countries. Journal of Economic Perspectives, 24(1), pp. 203-224.

Dabla-Norris, E., Misch, F., Cleary, D. \& Khwaja, M., 2017. Tax administration and firm perfomance: new data and evidence for emerging market and developing economies, Washington, DC: IMF Working Paper No. 95.

Djankov, S. et al., 2010. The Effect of Corporate Taxes on Investment and Entrepreneurship. American Economic Journal: Macroeconomics, pp. 31-64.

Dyreng, S. D., Hanlon, M., Maydew, E. L. \& Thornock, J. R., 2017. Changes in corporate effective tax rates over the past 25 years. Journal of Financial Economics, Volume 124, pp. 441-463.

Farre-Mensa, J. \& Ljungqvist, A., 2016. Do measure of financila constraints measure financial constraints?. The Review of Financial Studies, 29(2), pp. 271-308.

Gal, P., 2013. Measuring total factor productivity at the firm level using OECD-ORBIS, Paris: OECD Publishing.

Gemmell, N. et al., (forthcoming). Corporate taxation and productivity cath-up: evidence from European Firms. Scandinavian Journal of Economics.

Gygli, S., Haelg, F. \& Sturm, J.-E., 2018. The KOF Globalisation Index - Revisited. KOF Working Papers, Issue 439.

IMF, 2017. Upgrading the tax system to boost productivity. In: Fiscal monitor. Washington, DC: IMF Publisher, pp. 1-48.

Johansson, Å., Bieltvedt Skeie, Ø., Sorbe, S. \& Menon, C., 2017. Tax planning by multinational firms, Paris: OECD Publishing.

Leibrecht, M. \& Hochgatterer, C., 2010. Tax competition as a cause of falling corporate income tax rates: a survey of empirical literature. Journal of Economic Surveys, 26(4), pp. 616-648. 
Maffini, G., Xing, J. \& Devereux, M. P., 2016. The impact of investment incentives: evidence from UK corporation tax returns. s.l.:Oxford University Centre for Business Taxation, Working Paper Series, No. 16/01.

Mankins, M. C. \& Garton, E., 2017. Time, Talent, Energy. s.1.:Harward Business Review Press.

Mukherjee, A., Singh, M. \& Zaldokas, A., 2017. Do corporate taxes hinder innovation. Journal of Financial Economics, Volume 124, pp. 195 - 221.

Sorbe, S. \& Johansson, A., 2017. International tax planning, competition and market structure, Paris: OECD Publishing.

Zwick, E. \& Mahon, J., 2017. Tax policy and heterogenous investment behavior. American Economic Review, 107(1), pp. 217-248. 
Annexe A.

Figure A.1. Trends in effective taxation, by country

France

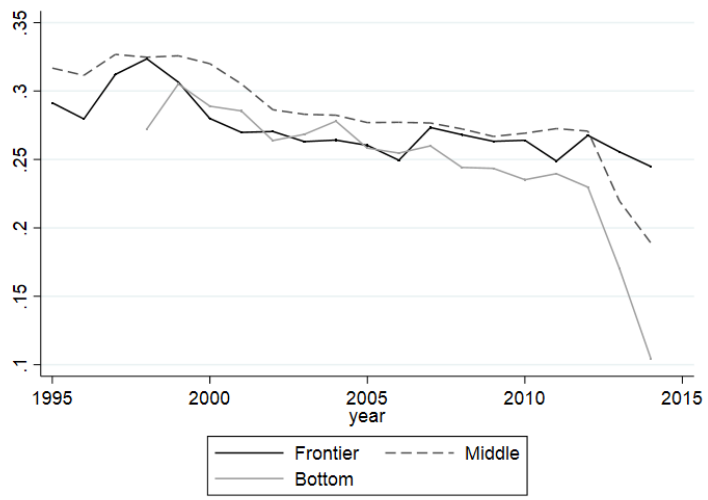

Germany

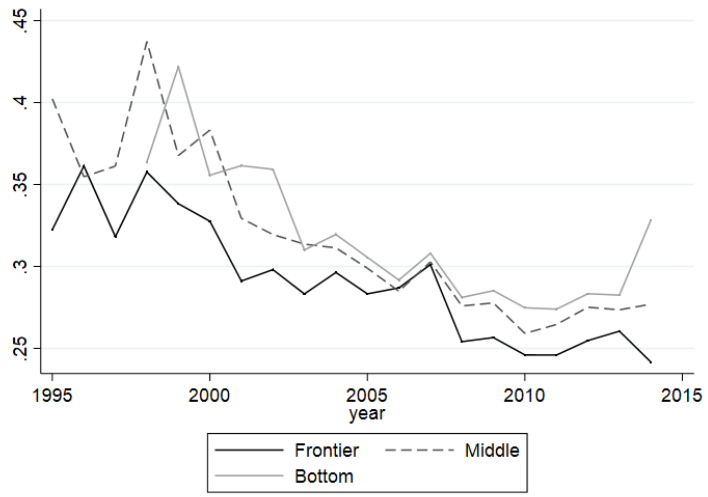

Korea

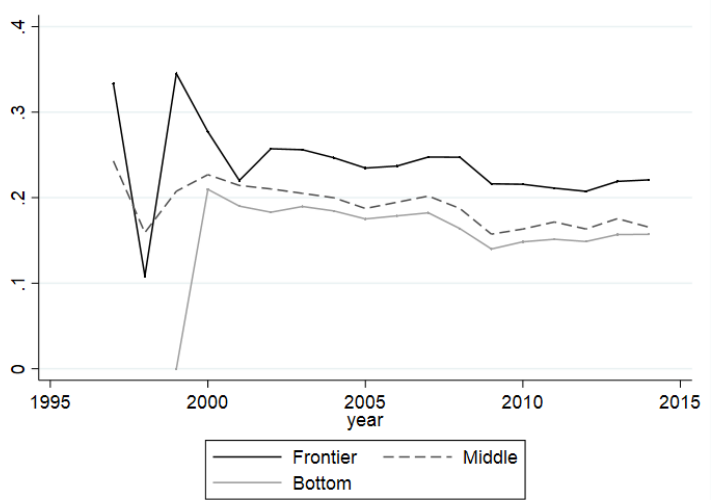

Great Britain

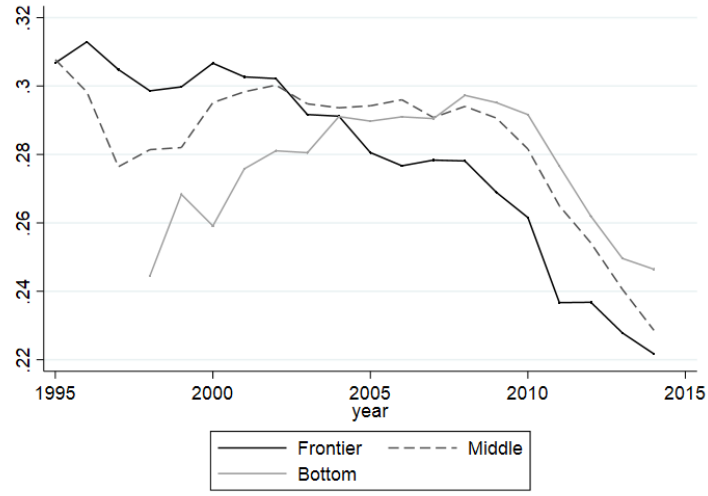

Italy

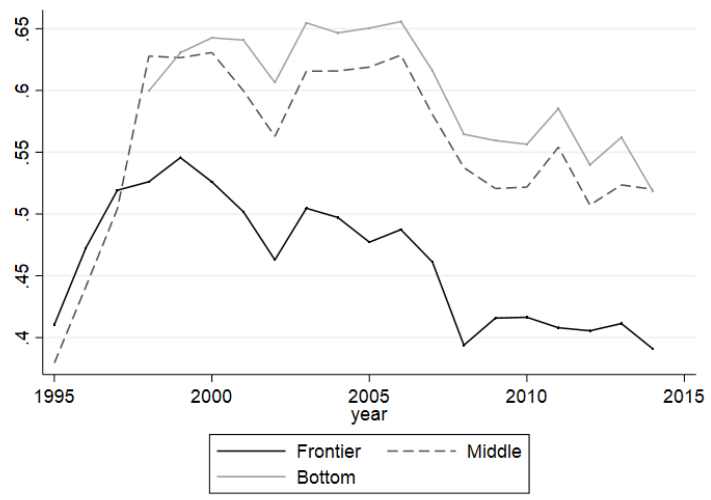

Sweden

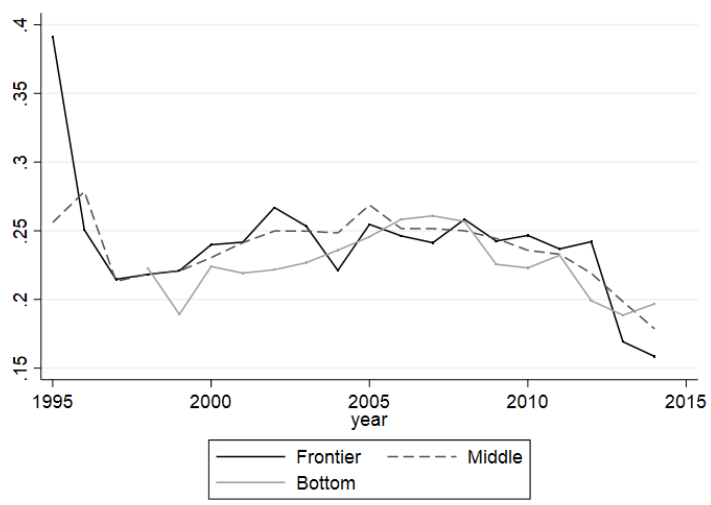

Source: Calculations based on ORBIS database. 